\title{
ECO-INNOVATION IN MUNICIPALITIES AS AN ELEMENT OF SMALLER AGGLOMERATIONS SUSTAINABLE DEVELOPMENT - CASE STUDY
}

doi: 10.2478/cqpi-2019-0015

Date of submission of the article to the Editor: 24/04/2019

Date of acceptance of the article by the Editor: 12/05/2019

\author{
Anna Zelga-Szmidla ${ }^{1}$ - orcid id: 0000-0002-7458-1675 \\ Katarzyna Kapustka ${ }^{2}$ - orcid id: 0000-0003-4890-2807 \\ ${ }^{1}$ Czestochowa University of Technology, Poland \\ ${ }^{2}$ Clausthal University of Technology, Germany
}

\begin{abstract}
Management in accordance with the principle of sustainable development is one of the basic aspects of environmental protection, and is nevertheless important in macroeconomic management (eco-innovations in national regulations) as well as in micro-regulations (municipal regulations). The municipalities authorities are obliged to preventing the negative effects of environmental degradation, preventing pollution, providing information on the state of the environment, cover the environmental policy, in order to ensure the land advancement in accordance with the principles of sustainable development. The implemented projects should mainly improve the living conditions of the inhabitants. That is why eco-innovative activities introduced in individual, small territorial areas (municipalities) are becoming more and more important. The paper is based on a case study as a recognized method of analyzing and discussing authentic situations used in management sciences.

Keywords: eco-innovations, sustainable development, knowledge management, regional innovations, local government
\end{abstract}

\section{INTRODUCTION}

The volatility of the global market has caused that in world literature, problems of innovation are being taken more and more often (Curvisanos and Mackenzi, 2014; Schumpeter, 1994; Porter, 1990 ; Porter, 1998). The term itself comes from Latin and means renewal and according to the interpretation of "introducing something new, novelty, reform", it can also be pointed out that innovation is "something that has not been there before, something that has completely new technology" (Wierzbicki and Nowodziński, 2019). There are many criteria for the division of innovations. The four basic types of innovative solutions are (Oslo Manual, 2005): marketing, product, process and organizational innovations. At the same time, the key criterion for the allocation of innovations to a selected group includes market analysis as a reference 
point (Tidd et al., 2005). Innovations can also be divided on the basis of the degree of novelty, area, scope of change or the genesis of creation. In this case, the strategies set the framework by which innovations should be introduced, and the types of strategies are mentioned: active, passive and responsive.

\subsection{Innovation and eco-innovation in literature}

Although innovations become crucial for enterprises in every economy, it also applies to local government units (Garces-Averbe and Canon-de-Francia, 2017) Sustainable development includes the following dimensions: economic, social and ecological, according to which local government units (LGUs) must operate. Eco-innovation is closely related to sustainable development (Sauve et al., 2016). In the literature terminology is taken up by many authors as one of the first on eco-innovativeness wrote: Fussler and James (1996) or Kanerva et al. (2009). Eco-innovativeness concerns every form of innovation, as a result of which the environment will feel the reduction of the negative impact of activities related to the functioning of the enterprise. The Central Statistical Office of Eco-Innovation defines as a new or improved product, service, process, organizational or marketing method that bring environmental benefits compared to another solution (Foltynowicz, 2009). Generally, eco-innovation is a purposeful introduction of "something new or improved" in an enterprise or LGUs that aims to improve the environment in which the unit operates. The main goals include improving the relationship between the environment and the community. Table 1 presents types of eco-innovations that function in the literature.

Table 1

Types of eco-innovation

\begin{tabular}{|c|c|}
\hline $\begin{array}{l}\text { "Product design } \\
\text { Eco-innovation" }\end{array}$ & $\begin{array}{l}\text { "Overall impact on the environment and material } \\
\text { input is minimized over the whole product's life } \\
\text { cycle" }\end{array}$ \\
\hline „Process eco-innovation” & $\begin{array}{l}\text { "Material use, emissions and hazardous substances } \\
\text { are reduced, risks are lowered and costs are saved } \\
\text { in production processes" }\end{array}$ \\
\hline $\begin{array}{l}\text { "Organizational } \\
\text { eco-innovation" }\end{array}$ & $\begin{array}{l}\text { "Methods and management systems reorganization } \\
\text { pushing for closing the loops and increasing } \\
\text { resource efficiency" }\end{array}$ \\
\hline „Marketing eco-innovation” & $\begin{array}{l}\text { "Product and service design, placement, promotion, } \\
\text { pricing" }\end{array}$ \\
\hline „Social eco-innovation” & $\begin{array}{l}\text { "Behavioral and lifestyle changes, user-led } \\
\text { innovation" }\end{array}$ \\
\hline „System eco-innovation” & $\begin{array}{l}\text { "Entirely new systems are created with completely } \\
\text { new functions reducing the overall environmental } \\
\text { impact" }\end{array}$ \\
\hline
\end{tabular}

Source: (Doranova et al., 2016)

\subsection{Characteristics of eco-innovation in rural communes in Poland}

Since 1999, in Poland there is a three-tier administrative division. First-level units are 16 voivodships. In the second-level units there are the 380 poviats, including 66 cities with poviat rights and 314 poviats. The third degree is the commune, units in the number of 2477, including: 302 municipalities, 638 urban-rural communes and 1537 
rural communes. The commune is a local government unit with are a number of tasks. These include tasks on which environmental protection depends, i.e. tasks in the field of water management, sewerage, waste disposal, maintenance of cleanliness or taking care of greenery, etc. The tasks of municipalities are undertaken in several legal acts, including in the Law on Local Government (1990), the Act on Environmental Protection (2001) and others. In Figure 1 the numerical data in relation to the implemented eco-innovations in the European countries have been presented. As the leaders in the implementation of eco-innovation should be indicated Finland, Germany and Sweden. By contrast, the least-developed countries in this field are Bulgaria, Cyprus, Poland. Statistical data have shown that eco-innovation in Poland still needs to put a lot of effort to improve their position - which is also confirmed in other studies (Nitkiewicz, 2009; Nowicka-Skowron and Nitkiewicz, 2011; Ingaldi and Czajkowska, 2019; Ostraszewska et al., 2019; Skrodzka and Kiriliuk, 2019).

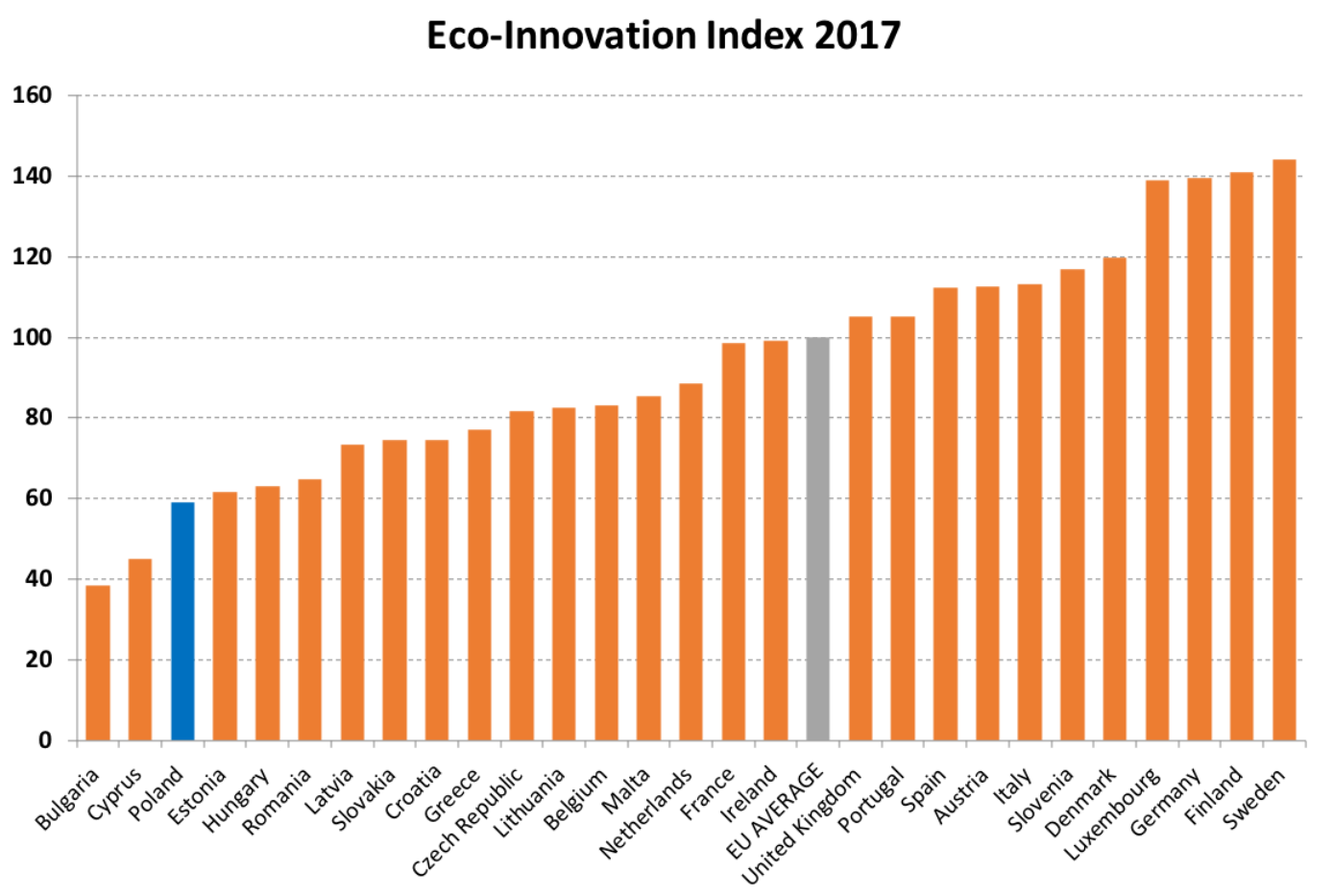

Fig. 1. Eco-Innovation Index 2017 in Europe - comparison of the implemented eco-innovations number in European countries

Source: https://ec.europa.eu/environment/ecoap/poland_en Access:14.04.2019

The term eco-innovativeness is a universal term and it can refer to different scale of operation. For an individual or sphere of a specific household, housing estate, village, commune, region - for the country and every business entity, enterprises or local government units.

\section{METHODOLOGY OF RESEARCH}

The paper presents the part of research on eco-innovativeness in a selected rural commune of the Silesian Voivodship. The selected commune has been qualified in the first 10th Ranking of Leaders of Local Government. In Poland, communes with a similar class are around 1500. Local authorities and residents have been working on a high locality for several years, which results from the conducted research. Eco- 
innovativeness will be an element of wider research on the state of the environment for the analyzed region.

\section{RESULTS AND DISCUSSION}

The area (commune) covered by the research is part of the Silesian agglomeration (one of the 96 rural communes in 167 all in the voivodship). It is characterized by a large forest area. There are areas of natural significance which, according to the strategic plans of the commune, will be used for recreational purposes. The values of the commune were appreciated by people from nearby communes and cities, as in recent years a significant migration of Silesian residents to the areas mentioned above has been observed. On the studied territory, the number of inhabitants and the modern single-family housing development is gradually increasing. Most importantly, the commune becomes a housing estate for young people, and thus further forecasts indicate an increase in migration trends (currently, the commune has around 12,000 residents). The location, as well as the neighborhood, with the second distinguished municipality (according to the ranking of the 14th edition of innovative local governments) testifies to the potential of mutual cooperation. Observed commune, owes its success to a well-managed local government and beneficial cooperation with residents. Since 2011 a development and promotion program has been established, which contributed to the current successes. From 2015, the commune in the analyzed national ranking every year gains a better and better position. And the development strategy, revitalization program, environmental protection program and low emission program are the basic documents that are in force in the commune. The overriding goal of local government officers is sustainable development of the commune, high quality of inhabitants' life and the preservation of the place natural values. The rural commune, included in the research, ranks on the top among the beneficiaries of EU funds, which is another success of a well-managed selfgovernment. The most important activities carried out by the self-government of the involvement are:

- lighting modernization;

- revitalization of the park's area;

- building of the amphitheater;

- construction of bicycle paths;

- renewal of the playground;

- modernization of buildings;

- remote reading system for water meters;

- providing a broadcast of the session of the commune council session for residents;

- other development plans related to the close location of the airport.

Indicated tasks are successively and consistently implemented, which favors the further development of the commune. At the self-government meetings, topics related to the implementation of new eco-innovations are constantly subjected to discussion. The residents' satisfaction is assessed on the basis of in-depth interviews, and with regard to the quality of life of residents, the most frequently asked questions are: What do they think about the selected local government authorities? Do they accept implemented tasks in the commune? What would they like to improve? Do they see the chances of commune development? How do they perceive the local government, which has been highly rated in the ranking of innovativeness? 
Observations of the functioning of public administration units, local governments, and public enterprises concern three basic dimensions within which one can talk about eco-innovations, as follows:

a. conceptual and planning aspects of comprehensive environmental protection in the process of strategic planning, setting goals and developing program documents;

b. organization and management (defined as social) integrating ecological aspects into the management system, organizational culture, procedures, administration, ways of implementing development projects, quality management, organizing orders and investments, facility and infrastructure management and the service provision process;

c. technology and implementation including issues of ecological efficiency of techniques and technologies used in the processes of service provision, in the process of investment implementation, performance of tasks or provision of public services

As the practitioners emphasize, the term evolves and eco-innovations can be divided into three groups:

Technological (implementation of new techniques or technologies in the process of providing communal services);

1. Organizational (regarding the method of providing municipal services or implementation of projects concerning, for example, the implementation of environmental management systems);

2. Social (involvement of human capital).

Eco-innovations in communes are defined as undertakings with the main aim: to reduce the negative impact on the environment (Lesníková and Schmidtová, 2019). Examples of activities that are implemented are: construction of sewage and water supply systems, energy efficiency of public buildings, led lighting, use of solar collectors, solar farms or heat pumps, ecological education and social dialogue or digitalization. Interestingly, in the area of eco-innovation, LGUs compete with each other, which in turn brings tangible benefits to the local community and the environment. Annually, the ranking of local governments is created. In this ranking, the local government units with the most developed economic, environmental, social and management are highlighted. In the area of economic sustainability, the ability to build a financial and economic foundation (supporting entrepreneurship, work, managing own wealth) is assessed. Another aspect of the assessment is the activities of local governments in the area of building social infrastructure (schools, nurseries, housing, playgrounds, etc.) and equipping the above institutions. When evaluating local governments, attention is paid to initiatives related to building awareness of the local community and involving residents in matters of self-government, cooperation with non-governmental organizations or participatory budget. Environmental activities are evaluated for this purpose, many projects are implemented at the local level, such as clean air care, use of renewable energy sources, sewerage and household wastewater treatment.

Residents assess the actions of local government officials very high, focus on the leader's resourcefulness, judging as "a very wise and resourceful communicative leader". They point out that a commune without such a leader and closest colleagues would not look the way it looks today. Residents themselves indicate that they often engage in activities organized in the commune. It was emphasized in the conversation 
that they perceive the role of the natural environment and indicate ecological awareness. The analyzed commune fulfills the role of an eco-innovative commune worthy of imitation, especially for the region of the Silesian Voivodship.

The name of the commune has been intentionally omitted because this paper is only a part of a more extensive study that has not yet been completed. But preliminary analyzes have helped to set the thesis: proper management of the local government, close cooperation with residents and an open approach to innovation (in particular eco-innovation) favors the social and economic development of smaller agglomerations. There is a close correlation between improving the quality of inhabitants' life and the number of implemented changes with eco-innovation markings.

\section{CONCLUSION}

Eco-innovativeness arose from the concept of continuous and sustainable development and is a practical way to achieve its basic goals and objectives. The concept and the definition of eco-innovativeness show that the most important element is the introduction of changes that consequently lead to resources savings of (non-renewable energy, raw materials, materials, water), as well as to reduction of pollutants and waste. The favorable changes as an effect of eco-innovation depends on the human factor and its involvement. The case study, as well as the literature of the subject, indicate that eco-innovations are an opportunity for the development and promotion of the region. The standard of inhabitants' living depends on the involvement of the commune authorities and the creativity of the local government. Spatial and ecological order, which includes spatial planning, properties management, protection of nature and the environment, as well as water management are the most important areas of the commune's activities. On the basis of the conducted research, it can be clearly stated: - proper management of human capital favors the development of eco-innovation - the inhabitants engage in the life of society;

- cooperation with partners, neighbors and residents favors to the lives of residents improvement and at the same time the commune development;

- confidence in local government promotes joint community activity;

- implementation of eco-innovation is conducive to the development of smaller agglomerations and improves their economic and social situation.

\section{REFERENCE}

Courvisanos, J., Stuart, M., 2014. Innovation economics and the role of the innovative entrepreneur in economic theory. Journal of Innovation Economics \& Management 2014/2 (14), 41-46.

Doranova, A., Roman, L., Bahn-Walkowiak, B., Wilts, H., O'Brien, M., Giljum, S., Kong,M.A., Hestin, M., 2016. EIO Bi-annual report. Policies and Practices for EcoInnovation Up-take and Circular Economy Transition.

Foltynowicz, Z., 2009, Ekoinnowacyjne szansą na rozwój. Ecomanager 1 (in Polish)

Fussler, C., James, P., 1996, Eco-innovation: A Breakthrough Discipline for Innovation and Sustainability, Pitman Publishing, Londyn.

Garces-Averbe, C., Canon-de-Francia, J., 2017, The relevance of complementarities in the study of the economic consequences of environmental proactivity: analysis of the moderating effect of innovation efforts. Ecol. Econ. 142, 21-30. 
Ingaldi, M., Czajkowska, A., 2019. Segregation and recycling of packaging waste in central Poland. IOP Conference Series: Earth and Environmental Science 214(1):012003 DOI: 10.1088/1755-1315/214/1/012003

Ingaldi, M., Dziuba, S.T., 2018. Ecological awareness of the residents of czestochowa region-results of survey International Multidisciplinary Scientific GeoConference Surveying Geology and Mining Ecology Management, SGEM.

Kanerva M., Arundel A., Kemp R., 2009, Environmental innovation: Using qualitative models to identify indicator for policy, United Nations University Working Papers Series, Maastricht.

Lesníková, P., Schmidtová, J., 2019. Environmental management in the context of corporate sustainability concept, CzOTO 2019, 1(1), 352-362. DOI: 10.2478/czoto2019-0045

Midor, K., Zasasdzień M., Directions of post-mining areas revitalization in a selected area of Polish-Czech borderland, W: 15th International Multidisciplinary Scientific GeoConference SGEM 2015. Science and technologies in geology, exploration and mining, 18-24 June 2015, Albena, Bulgaria. Conference proceedings. Vol. 3, Exploration and mining, applied and environmental geophysics. Sofia : STEF92 Technology, 2015, s. 219-227.DOI: 10.5593/SGEEM2015/B13/S3.029

Nitkiewicz, T., 2009. The role of strategic environmental assessment in the EU structural funds evaluation system in Poland, WIT Transactions on Ecology and the Environment, 120. DOI: 10.2495/SDP090552

Nowicka-Skowron, M., Nitkiewicz, T., 2011. Sustainable energy sector development through empowerment of individual consumers in EU, 6th International Scientific Symposium on Electrical Power Engineering, ELEKTROENERGETIKA 2011, 274277, Slovak Republic

Oslo manual, 2005. Guidelines for collecting and interpreting innovation data (3rd ed.), OECD Publishing, Luxembourg.

Ostraszewska, Z., Tylec, A., Vasylyk, S., 2019. The role of human resources in the creation of innovation position of Poland - comparative analysis to EU countries based on SII Index, CzOTO 2019, 1(1), 902-911. DOI: 10.2478/czoto-2019-0115

Porter, M., 1990. The Competitive Advantage of Nations, The Free Press, New York.

Porter, M., 1998. Clusters and the e New Economics of Competition. Harvard Business Review, 77-90.

Sauve, S., Bernard, S., Sloan, P., 2016. Environmental sciences, sustainable development and circular economy: Alternative concepts for trans-disciplinary research. Environ. Dev. 17, 48-56.

Schumpeter, J.A., 1994. Capitalism, Socialism and Democracy. VI ed. Routledge, London and New York.

Skrodzka, W., Kiriliuk, O., 2019. Sustainability indicators and environmental safety management as illustrated with an example of the Polish energy sector, CzOTO 2019, 1(1), 398-405. DOI: 10.2478/czoto-2019-0051

Tidd, J., Bessant, J., Pavitt, K., 2005. Managing innovation: Integrating technological, market and organizational change (3rd ed.), John Wiley \& Sons, Chichester, West Sussex, England.

Wierzbicki, M., Nowodziński, P., 2019. Imitation and innovation in business environment Production Engineering Archives, 22, 36-40. DOI: 10.30657/pea.2019.22.07 